Lawrence Zelenak

Duke Law School

zelenak@law.duke.edu

\title{
Debt-Financed Consumption and a Hybrid Income-Consumption Tax
}

\begin{abstract}
The debate between proponents of income taxation and proponents of consumption taxation has focused almost exclusively on the differing treatment of savings under the two tax bases. This is odd, given that income and consumption tax bases also differ in their treatment of debt-financed consumption. This Essay addresses the largely-ignored question of the taxation of debt-financed consumption. It contends that a strong case can be made in favor of a hybrid income-consumption tax base under which taxation is triggered by the earlier of consumption or income, so that both debt-financed consumption and saved income are included in the tax base. The Essay explains how one might reasonably favor consumption tax treatment of consumer debt even if one favors strict accretion-style income taxation on the savings side. It also considers how the case for the proposed tax treatment of debt-financed consumption is strengthened if most life cycle savings are already taxed under a consumption tax model (as is the case under the current federal income tax). Adoption of the proposal would have significant consequences-largely favorable-for many taxpayers. If taxpayers use loans to smooth consumption by shifting spending power from higher-income later years to lower-income earlier years (as in the case of student loans to cover living expenses, and credit card debt incurred during periods of unemployment), then treating those loans as determinative of the timing of taxation will benefit taxpayers by shifting tax base inclusions from higher-bracket years to lower-bracket years. It might also be appropriate to allow the earned income tax credit (EITC) with respect to debt-financed consumption.
\end{abstract}

\section{Introduction}

Henry Simons famously defined the base of an ideal income tax (what has come to be known as Haig-Simons income) as "the algebraic sum of (1) the market value of rights exercised in consumption and (2) the change in the value of the store of property rights between the

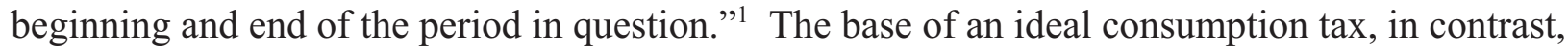

${ }^{1}$ Henry C. Simons, Personal Income Taxation 50 (1938). Simons built on an earlier definition offered by Robert M. Haig. Robert M. Haig, The Concept of Income-Economic and Legal Aspects, in The Federal Income Tax 1, 7 (Robert M. Haig, ed. 1921). 
is simply the market value of rights exercised in consumption during the period in question. ${ }^{2}$

Thus, an income tax includes saved (unconsumed) income in the tax base, whereas a consumption tax does not. In the voluminous literature on the relative merits of taxing income and taxing consumption, proponents of both bases agree that the tax base question turns on the merits or demerits of taxing savings. ${ }^{3}$ This is odd, because there is another difference in the tax bases-a consumption tax includes in its base debt-financed current consumption, but an income tax does not.

Although the difference in the treatment of debt-financed consumption is as fundamental as the difference in the treatment of saved income, and although the differing treatments of debtfinanced consumption are well understood by proponents of both tax bases, that difference has played virtually no role in the tax base debates. Occasionally proponents of a consumption base will note, as a point in favor of a consumption tax, the way in which inclusion of debt-financed consumption in the base of a progressive consumption tax can serve a tax-rate-smoothing function, ${ }^{4}$ but the core arguments for a consumption base are always concerned with the treatment of savings rather than of debt-financed consumption.

\footnotetext{
${ }^{2}$ Joel Slemrod \& Jon Bakija, Taxing Ourselves 195 (4 $4^{\text {th }}$ ed. 2008).
}

${ }^{3}$ Significant contributions to the debate include (among many other works) William D. Andrews, A Consumption-Type or Cash Flow Personal Income Tax, 87 Harv. L. Rev. 1113 (1974); Joseph Bankman \& David A. Weisbach, The Superiority of an Ideal Consumption Tax over an Ideal Income Tax, 58 Stan. L. Rev. 1413 (2006); Barbara H. Fried, Fairness and the Consumption Tax, 44 Stan. L. Rev. 961 (1992);Edward J. McCaffery, The Uneasy Case for Wealth Transfer Taxation, 104 Yale L.J. 283 (1994); and Alvin C. Warren, Jr., Fairness and a Consumption-Type or Cash Flow Personal Income Tax, 88 Harv. L. Rev. 931 (1975).

${ }^{4}$ David F. Bradford \& the U.S. Treasury Tax Policy Staff, Blueprints for Basic Tax Reform 112-13 (rev. 2d ed., 1984) Edward J. McCaffery, A New Understanding of Tax, 103 Mich. L. Rev. 807, 878-80 (2005). 
On the other side of the tax base debate, the indifference to the treatment of debt-financed consumption is even more striking; in the entire pro-income tax literature, there is not-to the best of my knowledge-a single statement of the position that an income tax is superior to a consumption tax because a consumption tax inappropriately burdens debt-financed consumption. Recognizing that the difference between income tax treatment and consumption tax treatment of saved income is significant mostly with respect to an affluent minority of taxpayers, income tax proponents sometimes suggest it would be more practical to replace the mass income tax with a mass consumption tax (which could be either an individually-based cash flow tax or a nonindividually-based value-added $\operatorname{tax}^{5}$ ) and an income tax (or a low-rate wealth tax in lieu of an income tax) imposed only on economic elites. ${ }^{6}$ These proposals are offered as ways of improving the administrability of the tax system, while preserving the substance of the income tax. The authors of the proposals do not mention, however, that the substitution of mass consumption taxation for mass income taxation would mean the inclusion of debt-financed consumption in the tax base. The implication is that these authors-along with, one suspects, most income tax proponents-have no fundamental objection to an earlier-of-consumption-orincome hybrid tax base.

${ }^{5} \mathrm{~A}$ value-added tax is basically the same tax as a retail sales tax, except the tax is collected from businesses at all stages of the production process, rather than only from retailers. Slemrod \& Bakija, supra note 2, at 233.

${ }^{6}$ Michael J. Graetz, 100 Million Unnecessary Returns: A Fresh Start for the U.S. Tax System, 112 Yale L.J. 261 (2002) (proposing the replacement of the current mass income tax with the combination of a VAT and an income tax applicable only to taxpayers with incomes of more than \$100,000); Deborah H. Schenk, Saving the Income Tax With a Wealth Tax, 53 Tax L. Rev. 423 (2000) (proposing the replacement of the current income tax with the combination of a consumption tax and a low-rate wealth tax). 
What explains the failure of income tax proponents to criticize the taxation of debtfinanced consumption under a consumption tax? It cannot be that the question is insignificant as a practical matter; there is far too much debt-financed consumption for that. Even setting aside the special case of home mortgage indebtedness and treating debt-financed college and graduate school tuition as an investment rather than as consumption, debt-financed consumption-through installment purchases of consumer durables, credit card debt, and student loans for living expenses-is a major economic phenomenon in the United States. The better explanation is that income tax proponents are simply not, as a matter of principle, committed to Haig-Simons taxation of debt-financed consumption. Were they to focus on the issue, most income tax proponents would probably be happy to endorse a hybrid income/consumption tax base, under which inclusion in the tax base occurs upon the earlier of consumption or income. Under the consumption portion of the hybrid tax base, consumption in advance of income (made possible by borrowing) would be taxed under a consumption tax model, with borrowed funds included in the tax base (with no offsetting deduction for the resulting debt-financed consumption expenditures) and later payments on the debt (both principal and interest) being fully deductible. Under the income portion of the hybrid base, saved income would also be taxed.

It is widely understood that the current "income" tax is actually a hybrid income/consumption tax, in the sense that it taxes some savings on the income tax model, while also taxing a great deal of the economy on either a cash flow consumption tax model (for example, most individual retirement accounts, employment-based retirement savings, and 
unrealized appreciation generally ${ }^{7}$ ) or a "tax prepayment"/wage tax model (for example, Roth individual retirement accounts, and equity-financed owner-occupied housing and other consumer durables $\left.{ }^{8}\right) .{ }^{9}$ The suggestion of this Essay is that Congress should consider adding one more significant consumption tax feature to the "income" tax; in addition to taxing many types of savings under a consumption tax model, perhaps Congress should tax consumer debt on a cash flow basis.

Part II of this article examines why the earlier-of-consumption-or-income hybrid might appeal to many income tax advocates. ${ }^{10}$ It begins by explaining how one might reasonably favor consumption tax treatment of consumer debt even if one favors strict accretion-style income taxation on the savings side. It then considers how the case for the earlier hybrid becomes even stronger if the decision has already been made to tax some savings on the consumption tax

${ }^{7}$ IRC $\S \S 401$ et seq. (employment-based retirement savings), 408 (individual retirement accounts), 1001 (generally imposing tax on asset appreciation only upon the "sale or other disposition" of an asset).

${ }^{8}$ IRC $\S 408$ A (Roth individual retirement accounts); Bradford \& U.S. Treasury Tax Policy Staff, supra note 4, at 77-78, 81 (describing the non-taxation of imputed rental income from owner-occupied housing and other consumer durables under the current income tax).

${ }^{9}$ On the hybrid nature of the current "income" tax with respect to savings, see Uneasy Compromise: Problems of a Hybrid Income-Consumption Tax (Henry J. Aaron, Harvey Galper, \& Joseph A. Pechman, eds., 1988); Edward J. McCaffery, Tax Policy Under a Hybrid IncomeConsumption Tax, 70 Tex. L. Rev. 1145 (1992). For the "tax prepayment "or wage tax approach, and its equivalence to a cash flow consumption tax under certain conditions, see Bradford \& U.S. Treasury Tax Policy Staff, supra note 4, at 110-11.

${ }^{10}$ The analysis in Part II takes as a given the decision to tax at least some savings under an income tax model. Although powerful arguments have been made for the superiority of a fullfledged consumption tax over either a full-fledged income tax or a hybrid base (see, e.g., Bankman \& Weisbach, supra note 3), this Essay is aimed at those who favor at least partial income taxation on the savings side. The target group includes the present Congress, and all likely Congresses in the near future. 
model. In particular, consumption tax treatment of consumer debt may be viewed as following from the exclusion of unrealized appreciation from the tax base, from the consumption tax treatment afforded to most retirement savings, or from the nondeductibility of personal interest expense. Although the case for the consumption tax treatment of consumer debt combined with accrual taxation of savings may be merely plausible, the case for consumption treatment of consumer debt in the presence of the consumption features of the current "income" tax is very strong.

Part III considers how an earlier hybrid might be implemented. It explains that the standard cash flow consumption tax treatment of loans to finance current consumption is inclusion of the loan proceeds in the tax base for the year of borrowing (and consumption), with later deduction of both principal and interest payments on the loan. It further explains that under certain conditions-including the applicability of the same tax rate in all relevant years-economically equivalent results can be obtained by simply ignoring consumer debt for tax purposes. Ignoring consumer debt for tax purposes means not including loan proceeds in the tax base and not allowing deductions for payments of either principal or interest; this is how the current income tax generally treats consumer debt. ${ }^{11}$ Part III goes on to explain, however, that the equivalency between cash flow taxation of consumer debt and the nondeductibility of consumer interest expense (under current law) breaks down for taxpayers who are subject to different marginal tax rates in different years. If taxpayers use consumer loans to smooth consumption by shifting some consumption from higher- income later years to lower-income

${ }^{11}$ IRC $\S 163(\mathrm{~h})$ disallows deductions for personal interest expense. However, IRC $\S \S$ 163(h)(2)(D) and 163(h)(3) exclude "qualified residence interest" (on both "acquisition indebtedness" and "home equity indebtedness") from the disallowance. 
earlier years (as in the case of student loans to cover living expenses, and credit card debt incurred during spells of unemployment), then treating those loans as determinative of the timing of taxation will tend to benefit taxpayers by shifting tax base inclusions from higher-bracket years to lower-bracket years. It might even be appropriate to allow the earned income tax credit (EITC) with respect to debt-financed consumption, in which case the earlier hybrid could cause a tax base shift from a positive tax rate to a negative tax rate.

Because of the great difference between true cash flow taxation and the nondeductibility of interest, in the presence of different marginal tax rates in different years, Part III concludes that current law's denial of a deduction for personal interest is not a satisfactory approximation of an earlier hybrid. It suggests, instead, that taxpayers be given the option of being subject to either regime-cash flow taxation of consumer loans, or interest expense disallowance under current law. Part III also considers nonbusiness loans other than loans simply to finance current consumption-in particular loans to finance the purchase of consumer durables and loans to cover college and graduate school tuition-and suggests how they might be treated under the proposed hybrid regime. Part IV briefly concludes.

\section{The Case for the "Earlier" Hybrid}

\section{A. Consumption, Savings, and the "Common Pool"}

Writing in 1955, Nicholas Kaldor argued that a consumption tax (an expenditure tax, in his terminology) is fairer than an income tax because "[a]n Expenditure base would tax people according to the amount which they take out of the common pool, and not according to what 
they put into it." ${ }^{\prime 2}$ In other words, consumption expenditures are appropriately taxed because consumption takes resources out of the "common pool" and appropriates them to the private benefit of the consumer, but savings are not appropriately taxed because savings-even private savings-contribute to the common good. Income tax advocates typically respond that Kaldor's "common pool" metaphor misrepresents the nature of private savings. As Alvin Warren has argued,

The image of a common pool certainly fails to capture the reality of existing legal relationships in our society if it is meant to suggest that all members of the society have equal access to the pool ... . That pool is not collectively owned, but held privately by shareholders whose shares are simply their claims on unconsumed product. The commonality of the common pool has only to do with the derivative benefit to society of saving and investment, not in any generality of ownership or control; nor is the aura of moral superiority that sometimes surrounds those who leave their goods in the pool justified. Accumulation of wealth in our society is not a matter of altruistically forgoing current consumption for the good of others. Rather, it is a matter of a saver choosing to defer until a later date either his own

${ }^{12}$ Nicholas Kaldor, An Expenditure Tax 53 (1955). Kaldor claims that his common pool analysis is derived from the following passage from Hobbes:

For what reason is there, that he which laboureth much, and sparing the fruits of his labor, consumeth little, should be more charged, than he that living idlely getteth little and spendeth all he gets: seeing the one hath no more protection from the Common-wealth than the other? But when the Impositions are layd upon those things which men consume, every man payeth equally for what he useth: Nor is the Common-wealth defrauded by the luxurious waste of private men.

Thomas Hobbes, Leviathan chap. 30 (1651).

Liam Murphy and Thomas Nagel have persuasively argued that the quoted passage does not, in fact, support the common pool argument. According to them, the passage is "most plausibly read as an argument that consumption is a better measure of the benefit that someone receives from the protection of the state than is income." Liam Murphy \& Thomas Nagel, The Myth of Ownership 112 (2002). 
consumption or that of an object of his bounty. ${ }^{13}$

Warren's claim is that Kaldor is wrong about savings-that far from being left in a common pool, savings constitute a private claim on on resources-not that Kaldor is wrong about consumption. Thus, an income tax proponent might agree with Kaldor's premise that the tax base should consist of material resources subject to the taxpayer's private control, ${ }^{14}$ and agree with Kaldor that consumption (including debt-financed consumption) would be part of that tax base, but disagree with Kaldor's conclusion that savings would not. The resulting tax base would be the earlier hybrid.

\section{B. Ability to Pay, Realization, and the Earlier Hybrid}

The above argument for the earlier hybrid might appeal even to those who favor an accretion income tax model with respect to savings, under which all unrealized appreciation would be included in the tax base. If the assumption that all savings will be taxed under the accretion model is abandoned in favor of a realization-based system, a different argument for the earlier hybrid emerges. It is commonly claimed that tax liabilities should be a function of different taxpayers' differing abilities to pay. ${ }^{15}$ Of course, saved income can be productive of ability to pay (as income tax proponents regularly point out), but the same is true of borrowed

\footnotetext{
${ }^{13}$ Alvin C. Warren, Jr., Would a Consumption Tax be Fairer than an Income Tax? 89 Yale L. J. 1081, 1094-95 (1980). Murphy and Nagel offer a similar critique of the common pool argument. Murphy \& Nagel, supra note 12, at 109-12.

${ }^{14}$ See Joseph Dodge, Taxing Human Capital Acquisition Costs-Or Why Costs of Higher Education Should not be Deducted or Amortized, 54 Ohio St. L. J. 927, 948 (1993) ("[T]he ethical obligation of citizens to contribute to the reallocative and redistributive functions of government is a function of the material resources they respectively control during a given budget period."). (1979).

${ }^{15}$ See, e.g., Alan Gunn, The Case for an Income Tax, 46 U. Chi. L. Rev. 370, 378-88
} 
money. Student loans used to finance subsistence consumption and credit card debt incurred to pay for basic needs during unemployment may not be indicative of any ability to pay tax, but the same is true of subsistence wages; as in the case of subsistence wages, the proper response of the tax system to subsistence borrowing is not to exclude it from the tax base, but to tax it at a low, zero, or even negative rate.

The problem with the ability-to-pay argument for including debt-financed consumption in a hybrid tax base is not that the argument is unpersuasive with respect to actual borrowing, but that it seems to prove too much. It is not only money actually borrowed which gives rise to ability to pay. Ability to pay also comes from unexercised borrowing capacity, yet no one has proposed that the tax base should include potential consumption foregone by failing to borrow as much as possible. ${ }^{16}$ Although it is not easy to explain why an analysis focused on ability to pay would tax savings on an accretion model while ignoring unexercised borrowing capacity, including only actual borrowing in the base of the hybrid tax makes good sense if the tax on savings has a realization requirement. Unrealized appreciation can certainly give rise to ability to pay tax under many circumstances, but it is excluded from the tax base because of valuation and liquidity concerns (even in situations where those concerns are of little or no significance). Unused borrowing capacity is unrealized in much the same way as appreciation in an unsold asset, and taxing it would be subject to similar objections. It may not be feasible for the tax

\footnotetext{
${ }^{16}$ Richard Goode has claimed, "In my view, the total increase in a person's power to consume marketable output has greater intuitive appeal as an indicator of ability to pay than the exercise of the power to consume has." Richard Goode, The Superiority of the Income Tax, in What Should be Taxed: Income or Expenditure 49, 52 (Joseph A. Pechman ed., 1980). Although Goode's claim implies that unexercised borrowing capacity should be included in the tax base, he does not note that implication; rather, he uses his claim only to argue for the superiority of an income tax to a consumption tax.
} 
administrator to determine whether a taxpayer could have engaged in more debt-financed consumption than he actually did, and to determine the dollar amount of such foregone debtfinanced consumption. In short, if the ability-to-pay principle is limited by a realization requirement on the savings side, it can reasonably be limited by a realization requirement on the borrowing side. The result would be the earlier hybrid imposed on realized investment income, and on realized ability to borrow to finance consumption.

\section{Cash Flow Taxation of Retirement Savings and the Earlier Hybrid}

Of course, the realization requirement is not the only way in which the current income tax departs from accrual taxation of savings. Perhaps the most fundamental of the other departures is the taxation of the bulk of retirement savings under the cash flow consumption tax model rather than under an income tax model. Cash flow consumption tax treatment is available for annual additions of as much as $\$ 46,000$ to employment-based defined contribution retirement plans. ${ }^{17}$ At the back end, there is no limit on the amount of distributions from defined contribution plans eligible for cash flow treatment, no matter how dramatic the investment returns within the plan. ${ }^{18}$ In the case of defined benefit retirement plans, annual benefits eligible for consumption tax treatment are limited to the lesser of $\$ 185,000$ or $100 \%$ of average

${ }^{17}$ IRC $\S$ 415(c)(1); Notice 2007-87, 2007-45 I.R.B. 966 (inflation adjustment for 2008). The usual treatment of a qualified retirement plan under the current income tax-inclusion in the tax base of the post-retirement distributions from the plan-is not cash flow consumption tax treatment in the strictest sense, because distributions are included in the tax base even if the taxpayer does not actually spend the distributions during the current year. Assuming, however, that the distributions are used to support the retiree's current consumption, the tax results are consistent with cash flow taxation.

${ }^{18}$ Former IRC $\S 4980 \mathrm{~A}$ imposed a $15 \%$ excise tax on aggregate annual distributions in excess of $\$ 150,000$ from tax-favored retirement plans, but it was repealed in 1997. Taxpayer Relief Act of 1997, Pub. L. No. 105-34, § 1073, 111 Stat. 948 (1997). 
compensation for the retiree's high three years. ${ }^{19}$ With limits this high, upper-middle class employees are commonly able to accumulate several million dollars of retirement savings taxed entirely on a cash flow basis. ${ }^{20}$ Despite the "income" tax label of the current tax, actual income taxation does not apply to the life cycle savings of middle class and upper-middle class taxpayers. Only the savings of the rich and near-rich-bequest savings and rather extravagant life cycle savings-are taxed under true income tax principles.

The challenge, then, is to discern the principle according to which the current tax system taxes some savings under consumption tax rules while taxing other savings under income tax rules, and to determine whether consumption tax treatment of debt-financed consumption would be consistent with that principle. ${ }^{21}$ As I have suggested elsewhere, the actual income tax can be understood as drawing an ability-to-pay distinction between moderate life cycle savings on the one hand, and bequest savings and excessive life cycle savings on the other. ${ }^{22}$ Amounts which one must save during one's working years, in order to maintain one's (non-lavish) lifestyle during retirement, can plausibly be viewed as giving rise to no current ability to pay tax. Those dollars should be excluded from the tax base during the working years, and taxed only when they

${ }^{19}$ IRC $\S 415(\mathrm{~b})(1)$; Notice 2007-87, 2007-45 I.R.B. 966 (inflation adjustment for 2008).

${ }^{20}$ For example, if a taxpayer retired with the right to receive $\$ 185,000$ annually from a defined benefit plan for the rest of his life, his life expectancy was 20 years, and the appropriate discount rate was $4 \%$, the present value of his rights under the plan would be slightly more than $\$ 2,500,000$.

${ }^{21}$ See McCaffery, supra note 9, at 1147 (arguing that there is no a priori reason to assume that an ideal tax system should treat all types of savings identically, and that a hybrid tax-such as consumption taxation of life cycle savings and income taxation of bequest savings-might be normative).

${ }^{22}$ Lawrence Zelenak, The Income Tax and the Costs of Earning a Living, 56 Tax L. Rev. 39, 54 (2002). 
are used to finance consumption during retirement-in other words, they should be subject to cash flow consumption taxation. By contrast, other savings-bequest savings and extravagant life cycle savings-give rise to current ability to pay tax, and should be subject to the income tax model.

Borrowing to finance consumption generally serves the same consumption-smoothing function as retirement savings, except in the opposite direction. Instead of smoothing consumption by shifting resources from a current high-earning year to a later low- or no-earning year, consumer borrowing smooths consumption by shifting resources to a current low- or noearning year (such as a year spent as a full-time student, or a year of unemployment or underemployment) from a later high-earning year. If cash flow taxation-including its smoothing effect on applicable tax rates in a system with progressive marginal rates-is appropriate when savings are used to finance deferred consumption, symmetry and consistency would be promoted by also applying cash flow tax treatment when borrowing is used to finance accelerated consumption.

The point can be made in a different way, by focusing on types of taxpayers rather than on types of savings and borrowing. Roughly speaking, the current income tax divides the population into three groups: (1) the poor, who, through the mechanisms of the standard deduction and personal exemptions, are not subject to the income tax at all; ${ }^{23}$ (2) the middle class, who are taxed on their consumption but who are not really subject to income taxation,

${ }^{23} \operatorname{IRC} \S \S 63(\mathrm{c})$ (standard deduction), 151 (personal exemptions). The poor may, however, be eligible for the refundable earned income tax credit, the refundable portion of the child tax credit, or both. IRC $\S \S 32$ (earned income tax credit), 24(d) (refundable portion of the child tax credit). 
because all or nearly all of their savings qualify for consumption tax treatment ${ }^{24}$ and (3) the rich, who are genuinely subject to income taxation on at least a portion of their savings. Given the decision to apply the consumption tax model to the middle class when it saves, it seems appropriate also to apply the consumption tax model to the middle class when it borrows.

Michael Graetz has proposed making explicit the two-tax regime implicit in the current income tax, by replacing the mass income tax with a value-added tax (VAT) and an income tax applicable only to upper-income taxpayers. ${ }^{25}$ The majority of taxpayers, who would be subject only to the VAT, would be taxed on a consistent consumption basis with respect to both savings and borrowing; they would not be subject to current taxation on their unspent earnings, but they would be subject to current taxation on their debt-financed consumption. A VAT pays no attention to the means by which consumption is financed. Like a retail sales tax, it includes consumption purchases in its base regardless of whether they are financed by current earnings, by savings, or by borrowing. Consistent consumption taxation of the middle class could be achieved without the disruption inherent in the adoption of a VAT, simply by including debt-

${ }^{24}$ As explained earlier (at text accompanying notes 17-19), the retirement savings of middle class workers are generally eligible for consumption tax treatment. The other major form of savings of the middle class, equity in owner-occupied housing, is generally subject to wage tax or "tax prepayment" treatment, under which amounts invested in housing are included in the tax base when invested, but the investment return (imputed rental income and appreciation) is generally not taxed. As explained later (at text accompanying notes 46-52), the effects of wage tax treatment closely resemble those of consumption tax treatment.

IRC $\S 401(a)(17)$ limits to $\$ 200,000$ the amount of annual employee compensation which can be taken into account under a qualified retirement plan. (The inflation-adjusted amount for 2008 is $\$ 230,000$. Notice 2007-87, 2007-45 I.R.B. 966.) In much the same way that the standard deduction and personal exemption serve to exempt the poor from the income tax in its entirety, § 401(a)(17) serves to exempt the middle class from real income taxation (as contrasted with consumption taxation).

${ }^{25}$ Graetz, supra note 6 . 
financed consumption in the base of the "income" tax. ${ }^{26}$

D. The Earlier Hybrid and the Deductibility of Personal Interest Under the Income Tax

The following discussion reaches, via a different route, the same bottom line as the immediately preceding discussion-that a strong case can be made for applying income tax treatment to the savings of the rich, while applying cash flow tax treatment to the savings and borrowing of everyone else. Where the previous discussion considered the connection between the tax treatment of qualified retirement savings and the cash flow taxation of debt-financed consumption, the focus here is on the connection between the deductibility (or nondeductibility) of personal interest expense under an income tax and the cash flow taxation of debt-financed consumption.

To understand the debate concerning the proper treatment of personal interest expense under a Haig-Simons income tax, one must first understand the income-versus-consumption tax base debate as it relates to savings to finance deferred consumption. Imagine a no-tax world in which Spender and Saver both have $\$ 100$ of wages in the current period (period one). Each has a choice between consuming $\$ 100$ in period one, or investing $\$ 100$ at an interest rate of $10 \%$ (the market rate) and spending the resulting $\$ 110$ on consumption in period two. Spender chooses $\$ 100$ of period one consumption, while Saver opts for $\$ 110$ of consumption in period two. With $10 \%$ as the prevailing discount rate, each has chosen a consumption package with a present value (from the perspective of period one) of $\$ 100$. Now suppose a cash flow consumption tax with a flat rate of $20 \%$ is introduced. After paying a $\$ 20$ tax in period one, Spender will be able to

\footnotetext{
${ }^{26}$ For a fuller discussion of the relative merits of the Graetz proposal and the approach suggested in this Essay, see text accompanying notes 97-101.
} 
consume $\$ 80$ in that period. Spending nothing in period one, Saver will owe no tax in that period. She will invest her entire $\$ 100$ of wages, which will grow to $\$ 110$ by period two. Her consumption tax in period two will be $\$ 22(20 \%$ of $\$ 110)$, leaving her with $\$ 88$ of consumption. The new tax decreases the consumption power of both Spender and Saver, but it does not disrupt the present value equivalence of their consumption packages. Still using a $10 \%$ discount rate, the present value (in period one) of Saver's $\$ 88$ consumption in period two is $\$ 80$, which is exactly the amount of Spender's period one consumption. ${ }^{27}$

The present value equivalence of Spender's and Saver's consumptions would not be preserved, however, if the new tax is an income tax rather than a cash flow tax. Assuming (as before) a tax with a flat rate of 20\%, Spender will still pay a $\$ 20$ tax on his wages and consume $\$ 80$ in period one. Saver will also pay $\$ 20$ tax in period one on her wages, and will invest the remaining $\$ 80$ at a pre-tax rate of return of $10 \%$. In period two Saver will pay income tax of $\$ 1.60$ on her $\$ 8$ of investment income, leaving her with $\$ 86.40$ of period two consumption. From the perspective of period one, applying a $10 \%$ discount rate results in a present value of $\$ 78.54$ for Saver's period two consumption-which is less, of course, than the $\$ 80$ value of Spender's year one consumption.

Both sides of the tax base debate agree with the above analysis, as a descriptive matter. The disagreement is about which tax base produces results which are preferable as a matter of

\footnotetext{
${ }^{27}$ Wage tax treatment would also preserve the present value equivalence of the no-tax
} world. With a $20 \%$ wage tax, Spender would simply pay a tax of $\$ 20$ on his wages, and consume the remaining $\$ 80$ in period one. Saver would also pay a $\$ 20$ wage tax in period one, and would invest the other $\$ 80$. The $\$ 8$ investment return would be tax free, so Saver would be able to consume $\$ 88$ in period two. The equivalence of cash flow taxation and wage taxation holds only if the same tax rate applies in all relevant years. For more on wage taxation as an alternative to cash flow taxation, see infra text accompanying notes 46-52. 
policy. To oversimplify a rich and nuanced debate, consumption tax proponents believe that it is appropriate to discount future consumption to present value for purposes of equity analysis, while income tax proponents do not. ${ }^{28}$ According to consumption tax proponents, given that Spender and Saver were equally well-off (in present value terms) in the no-tax world, horizontal equity requires that that equality be maintained in the presence of taxation. ${ }^{29}$ The cash flow tax passes this test, but the income tax does not. Champions of the income tax dispute the premise that present value analysis should be used in comparing consumption in different years. In the words of Barbara Fried,

$[\mathrm{O}]$ ne can justify discounting the utility of future consumption only by hypothesizing one of two things. Either (1) our pleasure at nominally equal amounts of consumption systematically declines as we age, at a rate exactly equal to the discount rate throughout our lifetimes, or (2) we systematically prefer our younger selves to our older selves, and thereby weight the subjective utility derived from later consumption at a rate that declines apace with the discount rate for money. Just to state both hypotheses is, one suspects, to refute them in most people's minds. ${ }^{30}$

If discounting of future consumption for purposes of tax equity analysis is not appropriate, then Saver should be taxed more heavily than Spender-as accomplished by the income tax but not by the cash flow tax-for the simple reason that Saver has greater (non-discounted) total consumption.

The argument for income taxation set forth above is with respect to the taxation of supra note 3 .

${ }^{28}$ For a particularly fine description and analysis of both sides of the debate, see Fried,

${ }^{29}$ See, e.g., Bradford \& U.S. Treasury Tax Policy Staff, supra note 4, at 36-37; Andrews, supra note 4, at 1167-69; Kaldor, supra note 12, at 87.

${ }^{30}$ Fried, supra note 3 , at $977-78$. See also Warren, supra note 3, at 1100 (“' $[\mathrm{I}] \mathrm{t}$ may be that a rational consumer would not discount consumption, qua consumption, even ex ante, in that each period in his life would be given equal weight."). 
consumption deferred by savings, but it also has implications for the mirror image question of how an ideal income tax should treat consumption accelerated by borrowing. The point can be illustrated by returning to the Saver/Spender hypothetical and adding a third character, Borrower. Borrower will also earn $\$ 100$ in period one, but he prefers to accelerate his consumption into period zero, by borrowing (at the $10 \%$ prevailing interest rate) against his future earnings. In the no-tax world, he would be able to borrow and consume $\$ 90.91$ in period zero. $^{31}$ If, instead, an income tax is in operation, how should Borrower be treated? In particular, should he be allowed to deduct his interest expense?

Suppose first that Borrower is not allowed to deduct the interest. In that case, his tax liability in period one will be $\$ 20$ (20\% of $\$ 100$ period one wages), leaving him with only $\$ 80$ available to pay principal and interest on the loan he took out in period zero. Accordingly, a lender will be willing to lend him only $\$ 72.73$ to finance period zero consumption. ${ }^{32}$ Compare the situations of Borrower and Spender under this income tax without a personal interest expense deduction. Each pays \$20 tax in period one, but Borrower has achieved only $\$ 72.73$ of consumption, compared with $\$ 80$ of consumption for Spender. Of course, the two amounts are equivalent in present value terms (because Borrower's consumption occurs a year before Spender's), but the adoption of an income tax with respect to savings was based on the rejection of the use of discounting for purposes of tax equity analysis. If present value analysis should not be applied in comparing consumption in different periods, then Borrower is less well-off than

${ }^{31}$ His period one earnings of $\$ 100$ would be just enough to repay the $\$ 90.91$ principal and pay the $\$ 9.09$ interest.

${ }^{32} \$ 72.73$ principal plus $\$ 7.27$ interest equals $\$ 80$. 
Spender, and so should have a lower tax liability. This is simply the mirror image of the Spender/Saver income tax analysis. The appropriately lower tax liability for Borrower can be reached by allowing him to deduct his interest expense against his period one wages. With the deduction, Borrower will be able to borrow and consumer $\$ 74.07$ in period zero. ${ }^{33}$ Using an analysis similar to the above, William Andrews concludes that once one has accepted the rationale for income taxation of savings, consistent application of the principle that consumption has (or should be treated as having) no time value compels the allowance of a deduction for personal interest expense. ${ }^{34}$

To the best of my knowledge, this Essay is the first discussion in the tax policy literature of the earlier hybrid as such. There has been considerable discussion in the literature, however, concerning the closely-related question of the proper treatment of personal interest expense under an ideal income tax. ${ }^{35}$ The questions are closely related because taxing Borrower under a

${ }^{33}$ Borrower borrows and consumes $\$ 74.07$ in period zero. In period one, he repays $\$ 74.07$ principal and pays $\$ 7.41$ interest. After deduction of the $\$ 7.41$ interest expense, his taxable income in period one is $\$ 92.59$ and his tax liability (at the rate of $20 \%$ ) is $\$ 18.52$. The principal, interest, and tax payments in period one add up to exactly the $\$ 100$ of period one wages.

${ }^{34}$ William D.Andrews, Personal Deductions in an Income Tax, 86 Harv. L. Rev. 309, 376, n. 116 (1972). See also Alan Gunn, Is an Interest Deduction for Personal Debt a Tax Expenditure?, 1 Canadian Taxation 46, 49, n. 22 ("[T] he choice of income rather than consumption as the tax base reflects a decision that there is no time value of consumption, or at least none that should count in determining tax liability."); Stanley A. Koppelman, Personal Deductions Under an Ideal Income Tax, 43 Tax L. Rev. 679, 718-724 (1988) (offering a detailed consideration of Andrews' position).

${ }^{35}$ Andrews' is only one of several positions on the deductibility of personal interest expense. Another school of thought reaches the same conclusion-that personal interest expense should be deductible in an ideal income tax-by a different route. According to Melvin I. White and Anne White, a deduction for personal interest expense is necessary in order to create tax parity between a taxpayer who finances current consumption by drawing down his own assets 
cash flow tax and taxing Borrower under an income tax without a personal interest expense deduction will produce equivalent results, if the same tax rate applies to Borrower in period zero and in period one. As explained above, under an income tax without a personal interest expense deduction Borrower borrows and consumes $\$ 72.73$ in period zero, and in period one pays $\$ 80$ on the loan (\$72.73 principal and \$7.27 interest) and \$20 tax (on \$100 of period one wages). Under a cash flow tax, Borrower borrows $\$ 90.91$ in period zero to finance current consumption; he must pay tax in period zero of $\$ 18.18$ on the borrowed funds, which leaves $\$ 72.73$ available for period zero consumption. In period one, his wages of $\$ 100$ are just sufficient to enable him to repay the $\$ 90.91$ principal and to pay the $\$ 9.09$ interest. In both cases, Borrower has $\$ 72.73$ of consumption in period zero and no consumption in period one.

As will be discussed later in this Essay, the equivalence of interest expense denial and cash flow taxation does not hold when relevant tax rates differ in different years. ${ }^{36}$ Because this limitation on the equivalency is of great real world significance, an income tax without a personal interest expense deduction is not an adequate approximation of cash flow taxation of

(thus creating a quasi-deduction which offsets the investment income he would have earned if he had not drawn down the assets) and a taxpayer who finances current consumption by borrowing. Melvin I. White \& Anne White, Tax Deductibility of Interest on Consumer Debt, 5 Pub. Fin. Rev. 3, 4 (1977). See also Jerome Kurtz, The Interest Deduction Under Our Hybrid Tax System: Muddling Toward Accommodation, 50 Tax L. Rev. 153, 159 (1995) (making the same argument). On the other hand, Calvin H. Johnson contends that personal interest "is a cost of consumption [and] should not be deductible because costs of consumption are part of the tax base of income taxes." Calvin H. Johnson, Is an Interest Deduction Inevitable?, 6 Va. Tax Rev. 123, 128 (1986). See also Michael J. McIntyre, An Inquiry into the Special Status of Interest Payments, 1981 Duke L.J. 765, 774-77 (arguing that personal interest should be nondeductible as a consumption expenditure, and responding to the argument of White and White). For a thoughtful discussion of the various arguments on the deductiblity of personal interest in an ideal tax, see Koppelman, supra note 34, at 713-28.

\footnotetext{
${ }^{36}$ Infra text accompanying notes 46-52.
} 
debt-financed consumption. Nevertheless, the connection between denial of a deduction for personal interest expense and cash flow treatment of consumer loans is close enough that a proponent of the earlier hybrid must come to grips with the Andrews analysis of personal interest expense. If (as Andrews claims) denial of a deduction for personal interest is inconsistent with a fundamental premise of income taxation (i.e., that consumption has no time value), then to the extent that cash flow treatment of debt-financed consumption mimics the effects of interest deduction denial it seems vulnerable to the same charge of inconsistency.

It is easier for a proponent of the earlier hybrid to respond to the inconsistency charge in the context of the actual income tax-with its cash flow treatment of the life cycle savings of the great majority of taxpayers-than it would be to respond in the context of an ideal income tax which applied income tax principles to all savings. In the context of the actual income tax, an earlier hybrid proponent could respond that the current regime reflects-in the core case of reasonable levels of life cycle savings-acceptance of the Saver/Spender equity argument for cash flow taxation, and rejection of the income tax proponents' claim that consumption should be viewed has having no time value. If so, then the combination of cash flow treatment on the savings side (for qualified retirement savings) and cash flow treatment of debt-financed consumption, both applicable to the large majority of taxpayers, would be perfectly consistent; cash flow treatment of both debt-financed consumption and normal life cycle savings would reflect adoption of the consumption tax principle that there is a time value element to consumption.

The remaining challenge for the proponent of the earlier hybrid would be to explain how consistent cash flow tax treatment for the bulk of taxpayers could reasonably coexist with 
income tax treatment for a significant portion of the savings of the rich. A plausible answer might proceed along the following lines. The consumption tax case for consumption timing neutrality-i.e., for preserving the pre-tax equality of the present values of the consumption packages of Spender and Saver-is, of course, about the tax treatment of different decisions about the timing of consumption. To the extent that taxation of saved income is not about the taxation of consumption, consumption-based analysis does not apply and income taxation may be appropriate.

But when (if ever) is the taxation of saved income not about the taxation of sooner-orlater consumption? Two possibilities come to mind. The first is bequest savings. Savings motivated by the desire to leave bequests are not about the consumption of the taxpayer doing the saving. They may be about eventual consumption by bequest recipients, but Deborah Schenk has argued persuasively that the Spender/Saver horizontal equity case for cash flow taxation applies only within individual lifetimes:

To some, Saver's failure to consume may be immaterial; the invested savings will be transferred to someone who will. . . . This argument is unpersuasive. It is not obvious why parity between Spender and Saver's Child must be maintained, even if one accepts that parity between Saver and Spender must be preserved. Saver's Child has not foregone current consumption in anticipation of future consumption. Her consumption ... is pure windfall and there is no reason why the tax system needs to preserve equality between her consumption and Spender's consumption [in an earlier year]. Furthermore, the argument weakens as future consumption is transferred from generation to generation. ${ }^{37}$

${ }^{37}$ Schenk, supra note 6 , at 462. Schenk's argument depends on the common sense notion that individuals, rather than dynasties, are the appropriate units for tax equity analysis. David Bradford, however, has suggested otherwise: "Consider two dynasties, identically endowed in the form of earning power of their successive generations. In one dynasty each generation consumes what it earns. ... Suppose a generation of one dynasty chooses to pass some of its earnings forward to future members. Is there a basis for assessing it with a heavier tax?" David F. Bradford, Untangling the Income Tax 159 (1986). 
Schenk concludes that a tax system could reasonably apply consumption tax treatment to savings targeted to the taxpayer's own future consumption, while applying income tax treatment to bequest savings. ${ }^{38}$ That is, of course, roughly the approach of current law. By Schenk's standard, current law seems to put lavish life cycle savings on the wrong (i.e., income tax) side of the divide, but that might be explained by the difficulty of distinguishing, prior to the taxpayer's death, between bequest savings and lavish life cycle savings (and also perhaps by a sense that tax equity for those who save to finance future consumption binges is not a pressing concern).

Decades ago, Henry Simons noted another respect in which the taxation of saved income may be about something other than the taxation of sooner-or-later consumption. According to Simons, "In a world where capital accumulation proceeds as it does now, there is something sadly inadequate about the idea of saving as postponed consumption. ${ }^{\prime 39}$ If the accumulation of wealth produces intangible benefits-such as peace of mind, political and social power, prestige, security, and independence-in addition to the possibility of future consumption, then the heavier taxation of Saver than of Spender under an income tax may be justified as a way of reaching those benefits. ${ }^{40}$ An income tax does not directly tax the intangible benefits of wealth, ${ }^{41}$ but the greater income tax burden imposed on Saver than on Spender may be justified by Saver's

${ }^{38}$ Id. at 463.

${ }^{39}$ Simons, supra note 1 , at 97.

${ }^{40}$ See, e.g., Murphy \& Nagel, supra note 12, at 115; Koppelman, supra note 34, at 700-03, 724; Schenk, supra note 6, at 463-67.

${ }^{41}$ Bankman \& Weisbach, supra note 3, at 1449. 
enjoyment of those benefits. As Deborah Schenk has explained, the point is "not that we should attempt to tax power [and other intangible benefits of wealth] directly, but that savers enjoy more than deferred [consumption] and therefore need not be taxed the same as current consumers." ${ }^{, 42}$ Simons' concern in the passage quoted above-invoking "a world where capital accumulation proceeds as it does now"-is obviously about the intangible benefits of great wealth, not the benefits of moderate levels of life cycle savings. It may be that only savings beyond ordinary retirement savings produce the sorts of intangible benefits with which a tax system ought to be concerned. If so, it would make sense to impose an income tax on (most of) the savings of the rich, without also imposing an income tax on the savings of other taxpayers.

Several commentators have recently offered powerful critiques of the intangible-benefitsof-wealth argument in favor of income taxation, on the grounds that such benefits are adequately burdened by a consumption tax. ${ }^{43}$ According to Joseph Bankman and David Weisbach,

A consumption tax, by taxing goods purchased with savings, taxes these intangible benefits. For example, assume that the knowledge of available consumption gives a saver the sense of security because she knows that when she desires or needs something, she will have the money available. The imposition of a consumption tax reduces the amount available. This, in turn, reduces the security (or power or prestige) associated with the savings. ${ }^{44}$

If one is persuaded by this critique, one might abandon income taxation altogether. For present purposes, however, that question can be set aside. Even assuming one is (rightly or wrongly) convinced that the savings of the rich should be subject to income taxation as a way of

\footnotetext{
${ }^{42}$ Schenk, supra note 6 , at 465 .

${ }^{43}$ Bankman \& Weisbach, supra note 3, at 1449; Daniel N. Shaviro, When Rules Change 106 (2000).

${ }^{44}$ Bankman \& Weisbach, supra note 3, at 1449.
} 
reaching the intangible benefits of wealth, it would be reasonable to conclude (as Congress appears to have concluded) that there is no need to apply the same tax regime to ordinary retirement savings.

In sum, the treatment of savings under the current income tax can be plausibly explained and defended as: (1) accepting the Saver/Spender equity analysis offered by consumption tax proponents with respect to savings for the purpose of deferred consumption, and accordingly applying consumption tax principles to ordinary life cycle savings; and (2) understanding great wealth as being about something more than a taxpayer's deferred consumption (i.e., as being about eventual consumption by others, or as being about the intangible benefits of wealth, or both), and accordingly applying income tax principles to wealth in excess of ordinary life cycle savings. Having opted for cash flow taxation of the savings of non-wealthy taxpayers, Congress could reasonably conclude that the borrowings of those same taxpayers should also be taxed on a cash flow basis. $^{45}$

\footnotetext{
${ }^{45}$ Stanley Koppelman argues-clearly correctly-that one could support a general income tax (rather than an income tax applicable only to the bequest savings and excessive life cycle savings of the rich) based on the intangible benefits of wealth. Koppelman, supra note 34, at 724. According to Koppelman, a decision to apply income tax principles to all savings in order to reach the intangible benefits of wealth has "no necessary implication for the treatment of personal interest expense." Id. His conclusion seems to be based on the dubious-and not explicitly stated-premise that being in debt does not produce intangible detriments which are the mirror image of the intangible benefits of wealth. If one believes in the existence of such intangible detriments, then across-the-board income taxation on the savings side would seem to call for across-the-board deductibility of personal interest (rather than either denial of a personal interest deduction or the sometimes-equivalent of cash flow taxation) on the borrowing side. Despite Koppelman's claim to the contrary, the intangible-benefits-of-wealth argument for income taxation meshes neatly with cash flow taxation of debt-financed consumption only if the intangible benefits argument is taken to apply only to wealth beyond normal life cycle savings.
} 


\section{Designing the Hybrid}

This section of the Essay considers some major issues in the design of an earlier-ofconsumption-or-income hybrid tax base. The goal is to design a tax system in which debtfinanced consumption is included in the tax base, but which otherwise retains the structure of the current income tax. Although there are important similarities between cash flow taxation of debt-financed consumption and the denial of a deduction for personal interest expense, the latter is not an adequate substitute for the former in the context of a tax with progressive marginal rates. Accordingly, this section of the Essay proposes that taxpayers with debt-financed consumption be allowed to choose between cash flow taxation and interest deduction denial (in a manner analogous to the choice provided under current law between cash flow taxation and wage taxation of elective retirement savings). This section also considers how a hybrid tax system should treat debt-financed consumption for purposes of the earned income tax credit (EITC), and how such a system should deal with debt-financed purchases of consumer durables (including owner-occupied housing) and with tuition loans.

\section{A. Cash Flow Taxation and Wage Taxation}

If the tax rate is constant over time, a wage tax can have the same ultimate effects as a cash flow consumption tax. For example, suppose a taxpayer has $\$ 10,000$ of current year earnings, which he wants to save for retirement (after reduction by any tax imposed in the current year). Suppose also that the relevant tax rate is $30 \%$ (both this year and in the retirement year in which he consumes $\$ 10,000$ plus the investment return) and that the investment triples in value between the current year and the retirement year of consumption. Under a cash flow tax, the taxpayer will be able to invest the entire $\$ 10,000$ (because no current tax is imposed on saved 
income). The $\$ 10,000$ will grow to $\$ 30,000$ by the retirement year of consumption, at which point it will be taxed at the rate of $30 \%$, leaving the taxpayer with $\$ 21,000$ to spend on consumption. Under the wage tax alternative, the taxpayer will pay $\$ 3,000$ tax in the year in which he earned the income, and will invest the remaining $\$ 7,000$. By the retirement year of consumption, the account will have grown to $\$ 21,000$. There will be no additional tax due in the year of consumption, so the taxpayer will be able to spend $\$ 21,000$ on consumption-the same result as under the cash flow consumption tax.

The equivalence does not hold if the tax rates are different in the two years. And the tax rates may be different in the two years even though the tax rate schedule does not change over time, if (as is typically the case) the taxpayer uses the retirement savings to shift consumption from a high income (and thus high tax rate) working year to a low income (and thus low tax rate) retirement year. In the above example, if the taxpayer's tax rate in the retirement year is $20 \%$ (with no other changes in the facts), then the taxpayer will be able to consume $\$ 24,000$ in retirement under the cash flow tax, compared with only $\$ 21,000$ under the wage tax alternative. Current law generally permits taxpayers to choose either cash flow treatment or wage tax treatment for elective retirement savings. ${ }^{46}$ Because shifting taxation from earning years to retirement years usually reduces the applicable tax rate (and also because the wage tax option is relatively new, especially with respect to employment-based savings), the bulk of tax-favored

\footnotetext{
${ }^{46}$ In the case of individual retirement accounts (IRAs), cash flow treatment applies to traditional IRAs (IRC $\S 408$ ), while wage tax treatment applies to Roth IRAs (IRC $\S 408 A$ ). In the case of employment-based elective retirement savings under IRC $\S 401(\mathrm{k})$, cash flow treatment is the norm, but since 2006 taxpayers have been able to elect wage tax treatment in lieu of cash flow treatment (IRC $\S 402 \mathrm{~A}$ ). Taxpayers are not, however, afforded a choice between cash flow and wage taxation of non-elective employment-based retirement savings; those savings are always subject to taxation under the cash flow model.
} 
retirement savings is subject to cash flow taxation. ${ }^{47}$

In the case of borrowing to finance accelerated consumption, there is again (as noted earlier in this Essay ${ }^{48}$ ) a close similarity between cash flow taxation and wage taxation. Suppose a taxpayer borrows $\$ 10,000$ in year one, at an interest rate of $10 \%$, for the purpose of financing various current consumption expenses. ${ }^{49}$ In year two, the taxpayer uses some of her year two earnings to pay both the $\$ 10,000$ principal and the $\$ 1,000$ interest on the loan. The applicable tax rate in both years is $30 \%$. Under a cash flow tax, the taxpayer will include the $\$ 10,000$ loan proceeds in her tax base in year one, and since she did not invest any of the proceeds she will not be entitled to any offsetting deduction. ${ }^{50}$ She will pay $\$ 3,000$ tax, and will be able to spend the remaining $\$ 7,000$ on consumption. In the second year, she will be able to deduct both the principal and interest payments on the loan (because she is able to spend no part of the $\$ 11,000$ payments on consumption in year 2), with the result that she owes no tax on $\$ 11,000$ of her year two earnings. ${ }^{51}$ Under the wage tax alternative, the loan proceeds will not be included in her year one tax base, so she will need to borrow only $\$ 7,000$ (on the assumption that her goal is to

\footnotetext{
${ }^{47}$ For example, in 200537.6 million households owned traditional (cash flow tax) IRAs, while only 16.1 million households owned Roth (wage tax) IRAs. Sandra West \& Victoria Leonard-Chambers, The Role of IRAs in Americans' Retirement Preparedness, Research Fundamentals (Inv. Co. Inst., Wash. D.C.), Jan. 2006, at 1, 2 fig. 2.

${ }^{48}$ Supra text accompanying notes $35-36$.

${ }^{49}$ Assume the borrowed money is used to finance pure current consumption-such as food, utilities, rent, and entertainment-rather than to purchase consumer durables or education. The special issues raised by borrowing to purchase consumer durables or to pay tuition are considered later, at text accompanying notes 84-92 (consumer durables) and 93-96 (tuition).

${ }^{50}$ Bradford \& U.S. Treasury Tax Policy Staff, supra note 4, at 111-12.

${ }^{51} \mathrm{Id}$.
} 
borrow enough to pay for $\$ 7,000$ of current consumption). Just as the initial borrowing has no tax consequences under the wage tax model, so the later payments of principal and interest have no tax consequences. ${ }^{52}$ When she earns $\$ 11,000$ wages in year two (not necessarily her entire wages for that year), and pays the entire $\$ 7,700$ principal and interest due on the loan, the wages will be included in the year two tax base and neither the principal nor the interest will be deductible. Thus, the after-tax wages of $\$ 7,700$ ( $\$ 11,000$ pre-tax wages minus a $30 \%$ tax of $\$ 3,300$ ) are just enough to enable her to pay off the loan. Under both tax systems, the taxpayer uses the combination of a loan in year one and $\$ 11,000$ of wages in year two to finance $\$ 7,000$ of consumption in year one.

As in the retirement savings situation, however, the equivalence of cash flow taxation and wage taxation breaks down if the tax rate is not the same in both years. If the taxpayer is in a lower bracket in year one than in year two (which is likely to be the case even if the tax rate schedules are identical in the two years, if the taxpayer is borrowing for the purpose of smoothing consumption), then cash flow treatment will produce more taxpayer-favorable results than will wage tax treatment. If the applicable tax rate is $20 \%$ in year one (with no other changes in the facts), then under the cash flow tax the taxpayer will owe only $\$ 2,000$ tax on a $\$ 10,000$ loan, and will be able to finance $\$ 8,000$ of year one consumption by borrowing in anticipation of $\$ 11,000$ of year two wages. Under the wage tax alternative, however, the $20 \%$ tax rate in year one is irrelevant, and the taxpayer will still be able to finance only $\$ 7,000$ of year one consumption by borrowing in anticipation of $\$ 11,000$ of wages in year two.

B. The Nondeductibility of Personal Interest: A Stealth Hybrid Tax?

${ }^{52}$ Id. at 112 . 
Although consumer interest has been fully deductible for most of the history of the federal income tax, since 1986 the Internal Revenue Code has provided that "personal interest" is not deductible. ${ }^{53}$ If cash flow taxation (which calls for inclusion of debt-financed consumption in the tax base) and wage taxation (which permits no deduction for personal interest expense) were fully equivalent, it would follow that since 1986 the so-called income tax has embodied the earlier hybrid. ${ }^{54}$ In that case, the purpose of this Essay would be not to urge cash flow taxation of debt-financed consumption, but merely to explain the nondeductibility of personal interest as an indirect way of implementing the earlier hybrid. ${ }^{55}$

When relevant tax rates differ in different years, however, the denial of a deduction for personal interest expense (i.e., wage tax treatment) will be a poor substitute for cash flow taxation. Whenever borrowing is used to accomplish forward-smoothing of consumption, denial of the interest expense deduction will overtax borrowers relative to the ideal of cash flow

${ }^{53}$ IRC $\S 163(\mathrm{~h})$. "Personal interest" is defined to include interest on any debt incurred to finance personal consumption, with the exception of certain debt secured by a mortgage on a "qualified residence" of the taxpayer.

${ }^{54}$ Even assuming full equivalence of cash flow taxation and wage taxation, however, the embodiment would be imperfect because of the continued deductibility of interest on home equity loans used to finance consumption. IRC $\S \S 163(\mathrm{~h})(2)(\mathrm{D}), 163(\mathrm{~h})(3)(\mathrm{C})$. The deductibility of interest on home equity indebtedness enables a taxpayer with equity in her home to borrow money (up to the lesser of $\$ 100,000$ or the equity in the home) with her home as security for the loan, use the borrowed funds to pay for consumption expenditures of any kind, and deduct the resulting interest expense.

${ }^{55}$ The Essay could also explain that adoption of the earlier hybrid as the norm would moot the deadlocked debate as to whether personal interest expense should be deductible under an ideal income tax. (For a summary of the debate, see supra note 35.) If the earlier hybrid were taken as the norm (in lieu of a pure Haig-Simons income tax), and if cash flow taxation and wage taxation were fully equivalent, then denial of a deduction for personal interest would implement the norm (and allowance of a deduction would not). 
taxation. ${ }^{56}$ The significance of this fact depends, of course, on the assumption that cash flow taxation is the ideal-in particular, on the assumption that the applicable tax rate(s) in any given year should be a function of the taxpayer's consumption during that year, rather than of the taxpayer's income during that year. That position has considerable intuitive appeal. Edward McCaffery has plausibly suggested that "[s]pending on life's necessities should bear little or no tax," whereas "[s]pending on ordinary consumer items should bear a higher rate of tax than spending on life's necessities," and "[s]pending on luxuries should bear a higher rate of tax than spending on ordinary consumer items." ${ }^{, 57}$ Implementing this view of progressive rates tied to levels of consumption requires, of course, a tax base keyed to consumption rather than income. In any case, for present purposes it is not necessary to make from scratch the case for consumption-based tax rates. It is enough to note that the legislative embrace of cash flow taxation with respect to the consumption-smoothing savings of the vast majority of taxpayers results in tax rate determinations based on consumption rather than on income, and that consistency calls for the same focus on consumption rather than income in the case of consumption-smoothing borrowing.

Given the significance of the rate issue under a tax system featuring progressive marginal rates, proponents of the earlier hybrid should not be content with the very imperfect approximation of cash flow taxation of debt-financed consumption produced by the nondeductibility of the personal interest. Proponents should urge that taxpayers at least have the option of paying tax on debt-financed consumption under cash flow principles rather than under

\footnotetext{
${ }^{56}$ This is illustrated by the example at text following note 52 .

${ }^{57}$ Edward J. McCaffery, Fair Not Flat 88-89 (2002).
} 
wage tax principles. When David F. Bradford and the U.S. Treasury Tax Policy Staff proposed a comprehensive cash flow tax as a replacement for the income tax, they suggested that taxpayers should be able to elect either cash flow taxation or wage taxation with respect to debt-financed consumption, precisely because of the attractiveness of the rate averaging effect of cash flow treatment under progressive marginal rates. ${ }^{58}$ Although Bradford and the Treasury Staff made their suggestion in the context of a proposal for a comprehensive and consistent consumption tax, the case for a cash flow option for debt-financed consumption is not weakened because Congress decides to retain income taxation for the bequest savings and lavish life cycle savings of the rich. The case for optional (cash flow or wage tax) treatment of debt-financed consumption is especially strong if the current optional treatment of elective retirement savings is taken as a given. ${ }^{59}$ If a cash flow/wage tax option is appropriate in the case of consumptionsmoothing savings, it should also be appropriate in the case of consumption-smoothing borrowing.

If she elected the cash flow option, a graduate or professional school student who borrowed to pay for her room and board (and other living expenses) would include her debtfinanced consumption in her tax base in her student years (when the applicable tax rate would be low or even zero), and would thereby gain the right to deduct payments of both principal and

The existence of alternative ways of treating . . l loans for tax purposes would give individuals considerable flexibility in the timing of their tax liabilities. This feature of the Cash Flow Tax is desirable because it would minimize the need for special averaging provisions. Averaging is desirable because increasing marginal rates would be applied to increases in the tax base for any single year.

Bradford \& U.S. Treasury Tax Policy Staff, supra note 4, at 112.

${ }^{59}$ For the current optional treatment of elective retirement savings, see supra note 46. 
interest in later (higher-bracket) years. ${ }^{60}$ Similarly, a taxpayer who incurred credit card debt or took out a home equity loan to smooth consumption during a period of unemployment (voluntary or involuntary) could elect to include borrowed amounts in the year of borrowing, ${ }^{61}$ and so qualify to deduct both principal and interest payments in later (higher-bracket) years. ${ }^{62}$

\section{The Economic Significance of Debt-Financed Consumption}

The practical significance of the cash flow option for debt-financed consumption depends, of course, on the prevalence of debt-financed consumption in the economy. The phenomenon is certainly significant in the case of graduate and professional students. According to a Report by the U.S. Department of Education, in the academic year $2003-04,42 \%$ of all graduate students (candidates for masters, doctoral, and first-professional degrees) took out

${ }^{60}$ Subject to a ceiling of $\$ 2,500$ of interest expense and a phaseout based on modified adjusted gross income, IRC $\S 221$ permits a taxpayer to claim a deduction for interest paid on any "qualified education loan," which is defined to include debt incurred to finance students" living expenses. To the extent a taxpayer would be able to take advantage of $\S 221$ under current law, cash flow taxation of a student loan would be less attractive than current law, if the same tax rate applied in all relevant years. In that case, the effect of a cash flow tax election would be to allow a deduction for repayment of loan principal (the interest being deductible even without the election), at the cost of an earlier inclusion of the loan proceeds. Assuming a single relevant tax rate, the tax cost of the inclusion would be nominally the same as the tax benefit of the principal deduction, but in present value terms the cost of the earlier inclusion would exceed the benefit of the later deduction. However, when the tax rate in the year of inclusion is low (or zero) and the rate in the later year of deduction is relatively high, even taxpayers eligible for a deduction under $\S 221$ would often be well-advised to make a cash flow election.

${ }^{61}$ This approach could be implemented with respect to credit card debt simply by comparing beginning-of-year and end-of-year balances; it would not be necessary for the tax system to track account balances during the year. McCaffery, supra note 57, at 133.

${ }^{62}$ IRC $\S 163(\mathrm{~h})(3)$ currently permits taxpayers to deduct interest on up to $\$ 100,000$ of home equity indebtedness. The question of whether a taxpayer eligible to take advantage of $\S$ 163(h)(3) under current law would benefit from a cash flow election is analytically identical to the question concerning a taxpayer eligible to take advantage of $\S 221$, discussed supra note 60 . 
student loans, in the average amount of $\$ 16,900 .{ }^{63}$ In the case of candidates for first-professional degrees, $78.4 \%$ took out student loans, in the average amount of $\$ 26,400 .{ }^{64}$ Moving from singleyear data to students' entire careers as graduate or professional students, the same Report indicates that $53.1 \%$ of graduate and professional students borrowed for graduate education at some point, with an average total amount borrowed of $\$ 35,000 ;{ }^{65}$ in the case of professional students the figures were $83.6 \%$ and $\$ 61,200 .{ }^{66}$ The available data do not allocate the debt totals between tuition and living expenses, but the Report does indicate that during the 2003-04 academic year graduate and professional students had average total nontuition expenses of $\$ 17,900 .^{67}$

Debt-financed consumption is also common during periods of unemployment. A recent study found that low-asset households (in particular, households in the second and third deciles of the asset distribution) respond to spells of unemployment by increasing their unsecured credit card debt by (on average) 11.5 to 13.4 cents for every dollar of lost earnings. ${ }^{68}$ Households higher in the asset distribution do not increase their unsecured credit card debt during periods of

${ }^{63}$ National Center for Education Statistics (U.S. Department of Education), Student Financing of Graduate and First-Professional Education, 2003-04, at 11, tbl. 4 (2006).

${ }^{64}$ Id.

${ }^{65}$ Id. at $94-95$, tbls. 2.11 and 2.12 .

${ }^{66} \mathrm{Id}$.

${ }^{67}$ Id. at 55, tbl. 1.13 .

${ }^{68}$ James X. Sullivan, Borrowing During Unemployment: Unsecured Debt as a Safety Net, $43 \mathrm{~J}$. of Hum. Resources 383, 385 (2008). Households in the bottom decile of the asset distribution do not increase their unsecured borrowing during unemployment, because of insufficient access to unsecured credit markets. Id. 
unemployment. ${ }^{69}$ Such households, however, tend to use borrowing against home equity to smooth consumption during unemployment. Another recent study found that homeowners with low levels of liquid assets who experienced unemployment shocks were $25 \%$ more likely than other homeowners to refinance their mortgages, and that such homeowners on average used at least two-thirds of the extracted home equity to finance current consumption. ${ }^{70}$ In short, debtfinanced current consumption is a sufficiently important economic phenomenon (even when distinguished from debt-financed tuition and debt-financed purchases of consumer durables) to make its tax treatment a significant issue.

\section{Cash Flow Taxation of Debt-Financed Consumption and the Earned Income Tax}

\section{Credit}

Under the current income tax, zero is not the lowest tax rate. During its phase-in range the refundable earned income tax credit (EITC) functions as a negative $40 \%$ marginal tax rate on the "earned income" of taxpayers with two or more qualifying children, as a negative $34 \%$ marginal tax rate for taxpayers with one qualifying child, and as a negative $7.65 \%$ marginal tax rate for taxpayers with no qualifying children. ${ }^{71}$ If the income tax is revised to permit taxpayers to elect cash flow treatment of consumer loans, the question arises whether the debt-financed consumption thereby included in the tax base should be treated as EITC-generating "earned

\footnotetext{
${ }^{69}$ Id. at 401.
}

${ }^{70}$ Erik Hurst \& Frank Stafford, Home Is Where the Equity Is: Mortgage Refinancing and Household Consumption, 36 J. of Money, Credit, and Banking 985, 1012 (2004).

${ }^{71} \operatorname{IRC} \S 32(\mathrm{~b})(1)$. 
income." ${ }^{72}$ Under the current structure of the EITC, the mere fact that an item is included in the taxpayer's tax base does not automatically make the item productive of EITC; investment income is included in a taxpayer's adjusted gross income, and is taken into account for purposes of the phase-out of the EITC, but it is not treated as earned income for purposes of the phasing-in of the credit. ${ }^{73}$ For EITC purposes, consumer loans included in the tax base could be treated in the same manner as investment income-significant in the phasing-out of the credit (and, also, of course, significant in the determination of pre-credit tax liability under the tax rate schedules of IRC § 1), but not eligible for the negative tax rates applicable to "earned income" in the phase-in range of the credit.

The difficulty in deciding whether debt-financed consumption should be treated as EITCgenerating arises because of two sometimes conflicting purposes of the EITC-assisting the needy and encouraging work force participation. (The goals conflict because conditioning eligibility for the credit on the existence of earned income means that the very neediest families-those with no earned income-receive no assistance.) On the one hand, the EITC is

\footnotetext{
${ }^{72}$ In the case of parents who are themselves full-time students, the rules regarding eligibility for the (nonrefundable) dependent care credit (IRC § 21) furnish a precedent for treating full-time students as if they were employed. The credit is ordinarily available only with respect to child care expenses incurred to enable the taxpayer to be "gainfully employed," and credit-generating expenses are ordinarily limited to the amount of the taxpayer's earned income. IRC $\S \S 21(b)(2)(A)$ (gainful employment requirement), 21(d)(1) (earned income limitation). A full-time student, however, is deemed to be gainfully employed, and to have earned income of either $\$ 250$ or $\$ 500$ (depending on the number of "qualifying individuals" in the student's household) for each month spent as a full-time student. IRC $\S 21(\mathrm{~d})(2)$.

${ }^{73}$ IRC $\S \S 32(a)(2)(B)$ (phase-out based on the greater of adjusted gross income or earned income, 32(c)(2) (definition of "earned income").
} 
designed to help needy families achieve a decent level of consumption, ${ }^{74}$ and loan-dependent families headed by graduate students or by involuntarily unemployed workers certainly seem to be appropriate beneficiaries of the credit from that standpoint. On the other hand, the EITC is also intended to promote and reward employment, ${ }^{75}$ and allowing the credit on the basis of loans in lieu of wages seems inconsistent with the employment-promoting goal.

There is a plausible response, however, to the objection that a loan-based EITC would be inconsistent with the work-promoting purpose of the credit. In the cases of student loans and unsecured credit card debt, lenders are looking to borrowers' future wages for repayment. ${ }^{76}$ If the lenders are sufficiently confident that future wages will be earned that they are willing to make the loans, perhaps the tax system should be sufficiently confident of future wages to grant the EITC on the basis of the debt-financed consumption. Of course, this would have the arguably perverse effect of awarding credits to those who are able to borrow (because lenders have confidence in their future earnings) over those who are not (because of lack of lender confidence), even though the latter group has the greater need. But this is very similar to the perversity inherent in awarding the credit to low-wage parents while denying it to no-wage parents, and is arguably acceptable for the same work-promoting reason (although in the case of

${ }^{74}$ On the anti-poverty purposes of the EITC, see generally Lawrence Zelenak, Redesigning the Earned Income Tax Credit as a Family-Size Adjustment to the Minimum Wage, 57 Tax L. Rev. 301 (2004).

${ }^{75}$ S. Rep. No. 94-36, at 33 (1975), reprinted in 1975-1 C.B. 590, 595 (mentioning promotion of employment as one of the purposes of the credit); H.R. Rep. No. 94-19, at 10 (1975), reprinted in 1975-1 C.B. 569, 573-74 (same).

${ }^{76}$ In the case of home equity loans there is another possible source of repayment, but even then lenders expect that repayment will often be financed by wages rather than by the value of the homes securing the loans. 
the credit based on loans rather than wages, the work promoted by the credit is work to be performed in the future).

Another likely objection is that a loan-based EITC could encourage excessive borrowing by families headed by graduate students and unemployed workers. Again, however, there is a plausible response-that borrowing would be encouraged only up to the point at which the combination of borrowing and actual earned income (if any) equaled the maximum creditgenerating amount. These amounts are quite low-in 2008, $\$ 8,580$ in the case of a taxpayer with one qualifying child, and $\$ 12,060$ in the case of a taxpayer with two or more qualifying children $^{77}$-and if taxpayers need to borrow up to these modest levels to finance the subsistence of themselves and their children, and if lenders are willing to make the loans, there is nothing wrong with the tax system encouraging such borrowing.

Yet another possible objection is that the arguments in favor of treating loans as creditgenerating "earned income" suggest that distributions to retirees from qualified retirement plans should also be treated as "earned income," yet current law does not so provide. ${ }^{78}$ The obvious response is that if the law is amended to treat loans as EITC-generating "earned income," it should also be amended to treat distributions from qualified retirement plans (and perhaps Social Security retirement benefits as well) the same way. ${ }^{79}$ The practical impact of this change would

${ }^{77}$ Rev. Proc. 2007-66, 2007-45 I.R.B. 970, §3.07.

${ }^{78}$ IRC $\S 32(\mathrm{c})(2)(\mathrm{B})(\mathrm{ii})$ (amounts "received as a pension or annuity" are not treated as earned income).

${ }^{79}$ If Social Security retirement benefits were treated as "earned income" for purposes of the credit, it might be appropriate to treat the benefits as "earned income" in their entirety, rather than only to the extent the benefits are included in gross income under IRC $\S 86$. 
not be huge, as relatively few retirees will have qualifying children in their care ${ }^{80}$ and many of the retirees who do have qualifying children would be entitled to little or no credit after the application of the phaseout based on adjusted gross income. ${ }^{81}$ As to those few remaining retirees-those supporting their grandchildren or other "qualifying children," and doing so in difficult financial circumstances-there is a strong argument that they should be entitled to claim the EITC based on their retirement income sources. True, allowing the credit in this situation would not encourage current employment, but it would aid the needy and it would reward the past employment which gave rise to the qualified plan distributions (or Social Security benefits).

The case for awarding the EITC based on debt-financed consumption (and on retirement income) is strong, but it is not overwhelming. Although the connection between the EITC and gainful employment is not destroyed by allowing the credit on the basis of consumer borrowing, it is undeniably attenuated. And if the concern about inappropriate encouragement of borrowing can be exaggerated, it is nevertheless a legitimate concern. In addition, there is an alternative way of relaxing the dependence of the EITC on current year income, which in some ways may be preferable to the approach considered here. Lily Batchelder has described how the current EITC rules penalize (for example) a parent making $\$ 30,000$ in one year and nothing the next

${ }^{80}$ The small credit for taxpayers without qualifying children is not available to taxpayers over the age of 64. IRC §32(c)(1)(A)(ii)(II). Even apart from that restriction, the no-child credit is fully phased out (in 2008) when adjusted gross income reaches $\$ 12,880$. Rev. Proc. 2007-66, supra note 77, $\$ 3.07$.

${ }^{81}$ Under current law, substantial portions of Social Security retirement benefits are excluded from gross income (and thus from adjusted gross income). IRC $\S 86$. If the EITC were amended to allow credits on the basis of distributions from qualified retirement plans, it might be appropriate to modify adjusted gross income for purposes of the EITC phaseout, to include all Social Security retirement benefits. 
year relative to a parent making $\$ 15,000$ each year, and has proposed addressing this penalty by permitting "targeted averaging" of earned income over a two year period for purposes of EITC calculations. ${ }^{82}$ Compared with the approach suggested here, Batchelder's averaging has the arguable virtues of retaining a strong connection between the existence of earned income and the availability of the credit, and of not creating a borrowing incentive. On the other hand, the approach proposed here has some arguable virtues of its own; for example, it provides parents with greater flexibility in setting the amount of their EITC-generating base, and it extends the benefit of the EITC to parents who are full-time students living on income-anticipating student loans. ${ }^{83}$ Whatever one decides, however, on the EITC issue-to treat debt-financed consumption as credit-generating, to adopt Batchelder's "targeted averaging" instead, or to leave the current rules unchanged-the case remains strong for the adoption of the earlier hybrid for all other income tax-related purposes.

\section{E. The Tax Treatment of Debt-Financed Purchases of Consumer Durables}

At the highest level of consumption tax theory, a taxpayer who purchases a consumer durable with his own (non-borrowed) funds would not include the expenditure in his tax base for the year of purchase, because he would not have consumed the durable in that year. Instead, the purchase price would be treated as a deductible investment (offsetting the inclusion of the wages used to make the purchase), and the taxpayer would include the annual rental value of the durable in his tax base for each year in which he continued to own and use the asset. Of course,

\footnotetext{
${ }^{82}$ Lily L. Batchelder, Taxing the Poor: Income Averaging Reconsidered, 40 Harv. J. on
} Legis. 395 (2003).

${ }^{83}$ Batchelder would not make full-time students eligible for her "targeted averaging" proposal. Id. at 421. 
this treatment would be highly impractical, and it has never been seriously proposed. Instead, the standard approach to consumer durables under cash flow consumption tax proposals is to abandon conceptual purity, by applying wage tax ("tax prepayment") treatment rather than cash flow treatment to consumer durables. Thus, no deduction is allowed for the durable in the year of purchase, and the stream of rental value from the asset is excluded from the tax base. ${ }^{84}$ The disallowance of a deduction in the year of purchase will usually result in taxation of current year wages used to make the purchase. However, if the taxpayer paid for the purchase with wages saved (and thus deducted) in prior years, then the purchase will be treated as dissavings triggering taxation in the current year of those earlier wages.

As explained earlier, wage tax treatment is not a perfect substitute for cash flow taxation for a taxpayer who has different applicable tax rates in different years. ${ }^{85}$ A particular problem in this context is the possibility that wage tax treatment of consumer durables may produce tax base "bunching" in the year of purchase-resulting in the applicability of inappropriately high marginal tax rates in the year of purchase (compared with the tax rates which would have applied if the durable had received cash flow treatment)-if wages saved over several years are used to pay for the purchase of an expensive durable (such as a vehicle or a residence) in a single year. In their Blueprints proposal for a cash flow consumption tax with wage tax treatment of consumer durables, David Bradford and the Treasury Department Staff addressed this issue by allowing taxpayers to elect out of the usual cash flow rules applicable to savings in "qualified accounts." Taxpayers could save outside of qualified accounts for their purchases of consumer

\footnotetext{
${ }^{84}$ Bradford \& U.S. Treasury Tax Policy Staff, supra note 4, at 108-09.

${ }^{85}$ Supra text accompanying note $46-52$.
} 
durables, with wage tax treatment applying to those savings. Since a taxpayer would have paid tax on non-qualified account savings in the year in which the wages were earned, the taxpayer could use those wages to purchase a consumer durable in a later year-in effect transferring his investment from one type of non-qualified account to another-without incurring a tax liability in the year of purchase. ${ }^{86}$

Given this general framework for the taxation of consumer durables, how should the tax system treat debt-financed purchases of consumer durables? Consistency with wage tax treatment on the asset side would call for wage tax treatment on the liability side, which would mean no inclusion of loan proceeds in income and no later deductions for payments of either principal or interest. Putting together the asset-side and liability-side rules, the tax consequences to a taxpayer who made a debt-financed purchase of a consumer durable would be: (1) no tax consequences in the year of the purchase, because the loan proceeds would not be included in the tax base and the asset purchase would not be treated as a deductible investment; and (2) no tax consequences in later years, because neither principal nor interest payments would be deductible, and the rental value would not be taxable. ${ }^{86}$

Even if the system allowed taxpayers to elect cash flow treatment of consumer durables debt in lieu of wage tax treatment, taxpayers would generally avoid the cash flow option because the inclusion of the amount borrowed in the tax base in the year of purchase would tend to cause tax base "bunching", with a resulting increase in applicable marginal tax rates. ${ }^{87}$ Nevertheless,

${ }^{86}$ Bradford \& U.S. Treasury Tax Policy Staff, supra note 4, at 110-11, 113.

${ }^{86}$ These are the same results as under the current income tax, given the nondeductibility of personal interest expense (IRC $\S 163(\mathrm{~h})$ ).

${ }^{87}$ Bradford \& U.S. Treasury Tax Policy Staff, supra note 4, at 112. 
there could be unusual situations in which a taxpayer would prefer to include loan proceeds in his tax base for the current year in order to generate deductions for payments of principal and interest in later years, and so the question arises whether taxpayers should be given that option. Blueprints proposed giving them that choice, ${ }^{88}$ and there is no obvious reason not to allow taxpayers that flexibility. Moreover, there is an important advantage to giving taxpayers the option to have consumer durables debt taxed under either system. Cash flow treatment should be the norm in the case of debt used to finance current consumption (as explained earlier ${ }^{89}$ ), whereas wage tax treatment should be the norm for debt used to purchase big-ticket consumer durables. If each norm were made mandatory, then the tax system would need rules to distinguish between current consumption debt and durables debt. But with taxpayers having both options in the case of both types of debt, the tax system can rely on taxpayers to sort things out themselves, and so avoid the need for rules to identify the different types of debt.

How does the proposed treatment of consumer durables debt compare with the treatment of debt-financed home purchases under the current income tax? Assuming taxpayers elect wage tax treatment of home mortgage debt (to avoid a tremendous amount of tax base bunching in the year of purchase), the proposed treatment and current law produce the same tax results-that is, no tax results-in the year of the debt-financed home purchase. There is an important difference, however, in later years. Whereas the wage tax approach again produces no tax consequences in later years (no inclusion of rental value and no deductions for payments on the loan), the current tax system produces a deduction for interest payments (without, of course, imposing tax on

\footnotetext{
${ }^{88}$ Id. at $112-14$.

${ }^{89}$ Infra text accompanying notes $56-62$.
} 
rental value). ${ }^{90}$ Many commentators have argued that current law is unreasonably generous in this respect, ${ }^{91}$ as it in effect combines wage tax treatment on the asset side (exclusion from the tax base of rental value) with income tax treatment on the liability side (the interest expense deduction) to produce results more taxpayer-favorable than consistent application of either approach. ${ }^{92}$ Thus, the less favorable treatment of home mortgages under the wage tax approach than under current law is arguably a point in favor of applying the earlier hybrid in this situation. If, however, Congress wanted generally to adopt the earlier hybrid while retaining the current generous treatment of taxpayers with home mortgages, it could allow a taxpayer electing wage tax treatment of her mortgage loan to deduct interest payments (but not principal payments) despite not having previously included the borrowed funds in her tax base. And if Congress wanted to extend a similar benefit to those taxpayers (probably few in number) electing cash flow treatment for their home mortgage loans, it could provide that inclusion of loan proceeds in the tax base entitles a taxpayer to deduct in later years both principal payments and twice the actual amount of interest payments.

\section{F. Tuition Loans}

How would an ideal consumption tax treat a taxpayer's payment of tuition expenses with his own (non-borrowed) money? The answer would depend on whether the expenses were

${ }^{90} \mathrm{IRC} \S 163(\mathrm{~h})(3)$.

${ }^{91}$ See, e.g., Slemrod \& Bakija, supra note 2, at 218-22; The President's Advisory Panel on Federal Tax Reform, Simple, Fair and Pro-Growth: Proposals to Fix America's Tax System 7075 (2005).

${ }^{92}$ Consistent application of wage tax principles would disallow the interest expense deduction, and consistent application of income tax principles would require taxation of the imputed rental income produced by the home. 
viewed as an investment in the taxpayer's human capital (i.e., to increase his future wageearning capacity), or as a current consumption expenditure (roughly speaking, as entertainment). Under the latter view, the expenditure should be included in the tax base like any other consumption item. At least in the case of tuition for graduate- and professional-level education, however, treating the entire cost as a human capital investment seems at least approximately correct. On that assumption, a cash flow tax should allow an immediate deduction for the tuition expense, and should tax the eventual return on the investment-in the form of increased wages-as it is realized and consumed..$^{93}$

In this context wage tax treatment (with no deduction of tuition expenses and no tax on the eventual investment return) is not a plausible alternative to cash flow treatment, because it would require a determination of the portion of the taxpayer's later wages which should be excluded from the tax base as the investment return on the already-taxed tuition payments. The consumption tax situation with respect to tuition is the opposite of that with respect to consumer durables, in the sense that wage tax treatment is mandated for consumer durables (because it is not practical to tax the investment return on consumer durables), whereas cash flow treatment is

\footnotetext{
${ }^{93}$ This differs in only one respect from the dominant scholarly view of the correct treatment of the same expenses under an ideal income tax. The dominant view is that an ideal income tax would allow amortization of the expenses over the taxpayer's earning years rather than an immediate deduction. See, e.g., Richard Goode, The Individual Income Tax 80-87 (1976); Daniel I. Halperin, Business Deduction for Personal Living Expenses: A Uniform Approach to an Unsolved Problem, 122 U. Pa. L. Rev. 859, 903-05 (1974); Marvin A. Chirelstein, Federal Income Taxation 133-35 ( $9^{\text {th }}$ ed. 2002). For a dissent from the dominant view, see Dodge, supra note 14. Despite the near-consensus on the issue among scholars, the current income tax allows neither a current deduction nor amortization for the bulk of graduate and professional school tuition. See Treas. Reg. § 1.162-5(b) (disallowing current deductions for most such expenditures); Sharon v. Commissioner, 66 T.C. 515 (1976), aff'd per curiam, 591 F.2d $1273\left(9^{\text {th }}\right.$ Cir. 1978), cert. denied, 442 U.S. 941 (1979) (not allowing taxpayer to amortize the cost of his law school education over his professional career).
} 
mandated for tuition (because it is not practical to exempt the investment return on tuition while taxing wages generally).

If the tax treatment of debt-financed tuition on the debt side is to be consistent with the treatment on the asset side, the proceeds of tuition loans should be included in the student's tax base (but only to be offset by a deduction for the tuition investment), and later payments of both principal and interest should then be deductible (typically offsetting a significant portion of the former student's current earnings). Should borrowing students be allowed to elect wage tax treatment of tuition loans in lieu of cash flow treatment? If a student made such an election, the consequences would be: (1) in the year of borrowing, a tuition deduction with no offsetting inclusion; and (2) in later years, fully taxable wages with no deduction for any payments (principal or interest) on the loan. It would be rare that a taxpayer would find these results preferable to cash flow treatment of the loan. The typical result in the year of borrowing would be a largely wasted tuition deduction, with the deduction amount exceeding the pre-deduction consumption included in the tax base. Although there is no compelling reason to deny borrowing students a wage tax option for tuition loans, and indeed there is an administrative advantage to allowing them that option, ${ }^{94}$ the vast majority of students would certainly opt for

${ }^{94}$ As noted earlier (at text accompanying note 89 ), to the extent taxpayers are allowed the same options with respect to loans for different purposes, there is no need for the tax system to include rules formally distinguishing loans for different purposes. If taxpayers are allowed cash flow and wage tax options with respect to loans to finance current consumption and loans to finance consumer durables (as this Essay has suggested they should be allowed), then giving taxpayers the same options with respect to tuition loans avoids the need for rules distinguishing the three types of loans. 
cash flow tax treatment of tuition loans. As noted earlier, ${ }^{95}$ most students would also opt for cash flow treatment of loans to cover living expenses, so the bulk of loans to graduate and professional students would be taxed under the cash flow model. Considering both types of loans together, the typical pattern for graduate and professional students would be: (1) the student elects cash flow treatment for both living expense loans and tuition loans, with the tuition deduction offsetting the inclusion of the tuition loan, but with the living expense loan remaining in the current year's tax base; and (2) in later years, as the taxpayer earns wages and pays back the loans, the taxpayer claims deductions for all payments on both types of loans. ${ }^{96}$

\section{G. A VAT-Plus-Income-Tax Alternative}

As noted earlier, Michael Graetz has proposed retaining the federal income tax only for taxpayers with incomes above $\$ 100,000$, and replacing the lost revenue with a new federal value-added tax (VAT) ${ }^{97}$ His proposal and the proposal offered here have very significant similarities. Both would embody the same basic hybrid, in that both would subject the bulk of taxpayers to consistent consumption taxation (of both savings and borrowing) while retaining income taxation for a substantial portion of the savings of wealthy taxpayers.

\footnotetext{
${ }^{95}$ Supra text accompanying notes 56-62.
}

${ }^{96}$ If one rejects the view of tuition as an investment, and insists that all tuition expenditures are personal consumption-a view which seems highly dubious on the merits, but which seems to be implicit in the disallowance of tuition amortization deductions under the current income tax-then a taxpayer electing cash flow treatment of student loans would include all loans taken out during a year (for both living expenses and tuition) in that year's tax base, with no offsetting tuition deduction. The result would be significant tax base bunching in the year of borrowing. Most students would probably want to avoid that result, by electing wage tax treatment for the tuition portion of the loan, thus excluding that portion of the loan from the tax base. Having made a wage tax election, the students would lose the ability to deduct later principal and interest payments on the tuition portion of the loan.

${ }^{97}$ Graetz, supra note 6. 
From one perspective, this Essay supports Graetz's proposal, by providing a policy explanation of why it might be appropriate to tax debt-financed consumption on a cash-flow basis while taxing some savings on an income tax basis. (Graetz himself does not offer a policy explanation for this; indeed, he does not mention the fact that the proposed VAT would tax debtfinanced consumption.) From another perspective, this Essay offers an alternative approach to achieving the same general sort of hybrid envisioned by Graetz. The approach proposed here arguably has significant advantages over the Graetz proposal, in several respects. First, it is much less disruptive of the current regime than is Graetz's proposal. The lesser disruption gives the approach proposed here greater political feasibility than Graetz's proposal, and also would make for an easier transition (on the assumption that both proposals are politically possible). Second, Graetz's proposal-in contrast with the approach suggested here-fails to provide an exemption from tax for the debt-financed subsistence consumption of full-time students and the unemployed. ${ }^{98}$ Third, if progressive marginal tax rates are desired throughout the rate structure, rather than only at the top end, the approach proposed here readily accommodates such rates, while a VAT does not. Finally, as Graetz has noted, "probably the most challenging" task in

${ }^{98}$ Graetz would provide relief from the VAT for low-income workers through an EITC replacement administered through the payroll tax system, and VAT relief for retirees through cost-of-living increases in Social Security benefits. Id. at 290-93. Graetz's proposed system would provide no tax relief for those who are neither employed nor receiving Social Security benefits. It would be technically feasible to design a VAT which would effectively exempt all subsistence consumption from tax, through the mechanism of sending each taxpayer (or family) a rebate check in the amount of the VAT burden on subsistence consumption. Lawrence Zelenak, Flat Tax vs. VAT: Progressivity and Family Allowances, 679 Tax Notes 1129 (1995). Whether a system featuring universal cash rebates would be politically feasible is a different question. 
designing his VAT-plus-income-tax is finding a workable substitute for the EITC. ${ }^{99}$ By contrast, the approach proposed here works well with the existing EITC. ${ }^{100}$ On the other hand, Graetz's proposal features the elimination of the tax return filing requirement for most Americans. If one considers this an overwhelming selling point, ${ }^{101}$ one might opt for the VAT-plus-income-tax despite the other points in favor of the approach offered here.

\section{Conclusion}

All sorts of hybrid tax bases are theoretically possible. One could, for example, turn the argument of this Essay upside-down, and claim that the best tax base is a "later" hybrid, under which the imposition of tax is justified only when a taxpayer has both earned income and consumed it. Although it is not easy to imagine the arguments for requiring society to defer its claim on private resources until both earning and consumption have occurred, the later hybrid is actually a fair description of the current federal income tax as it is experienced by most taxpayers. When income comes before consumption (in the case of retirement savings), taxation is deferred until the consumption finally takes place. And when consumption takes place before income (in the case of debt-financed consumption), taxation is deferred until the income is eventually earned. ${ }^{102}$ These two sets of rules seem to have developed independently of each

\footnotetext{
${ }^{99}$ Id. at 291.
}

${ }^{100}$ See the discussion supra, text accompanying notes $71-83$.

${ }^{101}$ For an argument that elimination of the return filing requirement should not necessarily be considered a selling point, see Lawrence Zelenak, Justice Holmes, Ralph Kramden, and the Civic Virtues of a Tax Return Filing Requirement, 61 Tax L. Rev. 53 (2007).

${ }^{102}$ As explained earlier (text accompany notes 48-52), however, the denial of a deduction for personal interest expense has effects which in some respects resemble those of cash flow 
other, with little or no consideration of whether they make sense in combination. The claim of this Essay is that they do not make sense when taken together; what would make sense is the consistent application of consumption tax treatment to the savings and borrowing of most taxpayers, combined with income taxation of most of the savings of the rich.

There is a plausible argument for combining cash flow taxation of debt-financed consumption with Haig-Simons income taxation of savings, based on idea that either consumption or income is a sufficient trigger for the imposition of tax. In the context of a tax system which generally applies cash flow principles to ordinary life cycle savings (which is to say, the actual federal income tax), the case for cash flow taxation of debt-financed consumption is compelling. In a sense cash flow taxation of debt-financed consumption is implicit in the current system's denial of a deduction for personal interest expense, but actual cash flow taxation is superior to deduction denial if applicable tax rates should be keyed to current consumption levels rather than to current income levels (a view already reflected in the tax rules governing retirement savings).

It is hard to see who would not favor-relative to current law-adoption of the hybrid proposed here. Consumption tax proponents should consider adoption of the proposed hybrid to be a move in the right direction. Income tax proponents have never objected to the treatment of debt-financed consumption under consumption tax proposals (directing all their attacks, instead, at the consumption tax treatment of savings). And cash flow taxation of consumer borrowing would present no major technical or administrative difficulties. It is not easy to find common ground between income tax advocates and consumption tax advocates in the great tax base

taxation of debt-financed consumption. 
debate, but there should be common ground here. 